\title{
Analisis Media Pembelajaran Anak Usia Dini Berbasis Teknologi Masa Pandemi Covid-19
}

\author{
Desti Pujiati', Dema Yulianto \\ destipujiati.ump@gmail.com¹, destipujiati@ump.ac.id¹, vulianto.dema@gmail.com² \\ Universitas Muhammadiyah Purwokerto ${ }^{1}$, Universitas Nusantara PGRI Kediri²
}

\begin{abstract}
IT (Information Technology) in education sector during the Covid-19 pandemic becomes great challenges. Information technology among education, educators and school programs are still interesting subjects to discuss. The internet quota from the Ministry of Education and Culture is an effort to help the students in learning process starts from Kindergarten up to Higher level. Combined research method and purposive sampling technique are used in this study. Distributing questionnaires and conducting interviews are implemented to collect the data. In learning process during the Covid-19 pandemic, the teachers or educators in Banyumas Regency began to develop and deepen their much needed capabilities of Information Technology. The results showed that the utilization of IT in Banyumas Regency has already been well provided, had a good internet connection, and gainned quota from the Ministry of Education and Culture. Media can be used are cell phones, laptop, social media such as Facebook, Instagram, whatsapp group, email, zoom, and google meet. Every effort was done to make the education success in every sub-district at Banyumas Regency. From the data obtained, almost $65 \%$ used Whatsapp Group effectively through video from cell phone, 20\% through Instagram, 5\% through YouTube, 5\% through zoom, and 5\% through google meet. In line with 21st century of education expert has four skills in active communication, collaborative, higher order thinking and problem solving related to education. There are also some other efforts can be done such as increasing learning and developing educational creativity. The success of learning in each component is able to influence each other.
\end{abstract}

Keywords: learning media, learning videos, whatsapp group and cell phone

\begin{abstract}
Abstrak
Tantangan bidang pendidikan yang perlu diupayakan melalui TI (Teknologi Informasi) saat pandemi Covid-19. Teknologi informasi dikalangan pendidikan, pendidik dan program sekolah masih menjadi bahan diskusi yang menarik. Kuota gratis dari Kemendikbud sebagai upaya membantu proses pembelajaran peserta didik. Mulai dari jenjang usia PAUD hingga jenjang perguruan tinggi. Metode penelitian kombinasi, menggunakan teknik pengambilan sampel purposive samplingdigunakan pada penelitian ini. Cara mengumpulkan data dengan melakukan pembagian kuisioner dan wawancara. Pembelajaran selama pandemi Covid-19 para pendidik di Kabupaten Banyumas mulai mengembangkan dan memperdalam kapabilitas Teknologi Informasi yang sangat dibutuhkan. Hasil yang didapat pemanfaatan IT di Kabupaten Banyumas yang sudah tersedia sangat baik, signal yang mendukung kuota penuh disubsidi oleh Kementerian Pendidikan dan Kebudayaan. Fasilitas media yang digunakan menggunakan $\mathrm{Hp}$, laptop, aktivitas media sosial fb, Instagram, whattshap group, email, zoom, dan google meet. Segala upaya dilakukan untuk memperjuangkan keberhasilan pendidikan di setiap kecamatan di Kabupaten Banyumas. Dari data yang diperoleh bahwa keefektifan menggunakan Whattshap Group $65 \%$ dengan video pembelajaran melalui hp, instagram $20 \%$, Youtobe $5 \%$, zoom 5\%,dan google meet $5 \%$. Sejalan dengan ahli pendidikan abad 21 memiliki empat keterampilan dalam pembelajaran komunikasi aktif, kolaboratif, pemikiran yang lebih tinggi dan pemecahan masalah dalam kaitannya dengan dunia pendidikan. Beberapa upaya yang telah dilakukan dapat berupa peningkatan pembelajaran dan pengembangan kreativitas pendidikan. Keberhasilan pembelajaran komponen satu dengan yang lain saling mempengaruhi.
\end{abstract}

Kata Kunci: media pembelajaran, video pembelajaran, whattshap group dan hand phone 


\section{PENDAHULUAN}

Layanan pendidikan berdampingan dengan sebuah kebutuhan manusia dalam kehidupan agar mencapai manusia yang mengikuti zaman dan terus berkembang. Pendidikan turut serta membangkitkan cara hidup bangsa, juga meliputi upaya yang telah dipertimbangkan secara matang untuk menciptakan suatu kondisi lingkungan sehingga dapat mengembangkan potensi yang telah dibawa sejak dini secara optimal. Pemerintah, pendidik sangat mengupayakan jalan keluar pembelajaran masa pandemi dengan banyak memberikan sistem kebijakan (Deyupere, 2021). Hal ini membutuhkan proses panjang terutama dengan pengkondisian guru untuk dapat menggunakan berbagai alat teknologi. Upaya yang dilakukan oleh Para pendidik di kecamatan kembaran, tim gugus guru berdiskusi jalan keluar terhadap situasi saat ini mengagendakan kegiatan workshop media teknologi, sistem pengajaran, kurikulum masa pandemi Covid-19. Mengundang pakar yang ahli dalam bidang $\mathrm{TI}$, penyusunan bahan ajar untuk anak usia dini. Proses itu dilakukan selama 2 bulan dengan tetap praktek langsung ke orangtua sebagai teman belajar di rumah. Pencapaian keberhasilan dalam berbagai pihak yang mendukung. Uji coba dilakukan oleh guru dan orangtua. Melihat perkembangan anak dengan cara belajar yang asyik dan menyenangkan dengan tetap mendahulukan sehat tidak menyampingkan akademik, melindungi diri dari Covid-19.

Banyak cerita yang dialami orangtua saat pembelajaran yang terjadi selama masa pandemi menyesuaikan kebutuhan belajar anak di rumah membeli fasilitas hp baru, mencari signal yang kuat untuk dapat mengakses internet, ada cerita penyimpanan hp digantung agar mendapatkan signal, sekedar ke warnet untuk dapat wifi, suka cita dirasakan orangtua mengupayakan mendukung pembelajaran. Ada beberapa orangtua yang penggunaan hp secara bergantian dengan anggota yang lain, bahkan yang mempunyai anak lebih dari satu, seklumit bagian cerita dari pendidikan. Dasar pendidikan bagi anak usia dini mampu melakukan proses belajar suatu hal dengan cara nyata, proses mendidik yang diberikan untuk anak usia dini harus menggunakan suatu hal yang memungkinkan anak mampu belajar secara konkret. Seorang pendidik ketika menyajikan penerangan yang ditujukan untuk anak usia dini menggunakan media supaya penerangan tersebut diterima serta dapat diserap dengan baik oleh anak dan diharapkan terjadi perubahan-perubahan perilaku seperti kemampuan-kemampuan dalam hal pengetahuan, sikap, dan keterampilan setelah proses penerangan berakhir.

Proses belajar pada anak usia dini saat ini menjadi pusat perhatian. Semakin berkembang ilmu pengetahuan serta teknologi akan memberi dampak yang sangat besar kepada beragam aspek kehidupan. Pendidikan memiliki peran yang penting untuk pengembangkan ilmu pengetahuan serta teknologi. Pendidikan di abad 21 merupakan pendidikan yang tidak kenal akan waktu, ruang, batas usia, dan gender. Pendidikandapat dikatakan baik apabila menggunakan dengan maksimal kemodernan ilmu pengetahuan serta teknologi supaya tujuan yang ingin dicapai dilakukan secara mangkus dan sangkil.

Berkaca pada UNESCO, terdapat empat pilar tujuan pendidikan yaitulearning to know, learning to do, learning to be, dan learning to live together. Konsep empat pilar menjadi rujukan dalam pembelajaran makna belajar proses yang bermakna, belajar mengaplikasikan ilmu, bekerja sama dengan tim, memecahkan permasalahan serta merancang program pembelajaran menjadi hakyang perlu ada. Linearitas program yang ada saling berkolaborasi antar gugus, sehingga membuat saling bertukar ide, dan menyusun program yang inovasi mendukung terwujudnya media abad 21.

Berbicara anak usia dini tentu tak asing lagi bagi pemerhati anak usia 0-8 tahun. Usia ini dikatakan golden age, semua yang dilihat, dipandang, dirasakan terserah seperti kapas putih masuk 
kedalam otak anak sebagai pengalaman hidup mereka. Dalam taraf perkembangan banyak hal yang menjadi pemicu agar dapat berkembang secara maksimal. Organ manusia memiliki panca budi indrya yang ada pada manusia rupanya dari mata, telinga, hidung, lidah, dan kulit. Masing budi indrya membantu proses anak mendapat penerangan belajar.

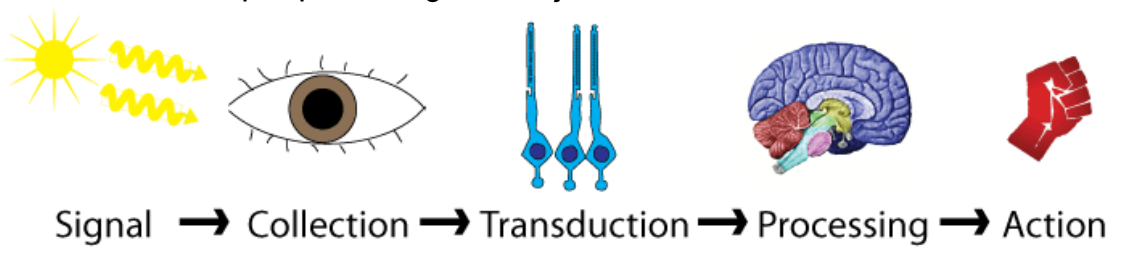

\section{Gambar 1. Panca Budi Indriya}

Panca budi indriya mendapat perhatian penuh, agar terpicu secara maksimal. Proses dari mata, dapat mengoperasikan kerja mata, telinga membantu proses kerja mendengar, hidung untuk dapat menghirup keadaan pembelajaran, lidah perasa saat belajar, dan kulit sebagai budi indriya merasakan. Komponen panca indriya menyatu bersama media pembelajaran yang diharapkan dapat menjadi penerang belajar anak masa pandemi covid-19.

Media pembelajaran untuk penerang belajar anak usia dini ada berupa akan dipaparkan sebagai berikut: (1) Video pembelajaran (animasi dirancang pendidik). Video pembelajaran sesuai tema pengajaran, tentu video interaktif, pendidik sebagai model berwujud menerangkan dengan gamblang proses belajar. (2) Zoom penerangan belajar, media zoom digunakan saat kegiatan anak satu kelas, dengan temu kangen lewat udara secara online. (3) Whattshap group paguyuban. Video pembelajaran sudah upayakan setiap hari sebagai bahan kegiatan yang akan di bagikan ke whattshap group paguyuban wali peserta didik. (4) Instagram sekolah, wali peserta didik, pencanangan anak belajar dengan pendampingan orangtua, hasil karya anak dapat di unggah ke insagram dengan tag instagram sekolah, ada juga hasil karya baik tertulis, video, gambar bisa diunggah ke medsos tentu dengan izin dari wali peserta didik. (5) Facebook, pencanang hampir sama dengan instagram. (6) Youtube, agar sekolah tetap eksis dengan kemajuan pengajaran yang di hasilkan oleh anak dengan hasil karya yang dapat diunggah ke youtobe. (6) Curriculum Individual masa pandemi dengan program sesuai kebutuhan peranak. Menjadi pemecah masalah yang baik bagi pengajar mengafiliasi program dengan panca budi indriya. Kurikulum disusun dengan kebutuhan anak, program yang dicanangkan dekat dengan anak. Wali peserta didik dan anak mudah melaksanakan belajar dengan mudah juga mendapat penerangan.

Pembelajaran dengan daring tepat menggunakan video pembelajaran respon penelitan diutarakan (Hutami, 2020). Perkembangan ilmu pengetahuan serta teknologi memiliki pengaruh pada media pembelajaran yang digunakan di lembagapendidikan (Marcomm, 2018). Penggunaan teknologiinformasi untuk proses pembelajaran di kelas sudah sebagai sesuatu yang dibutuhkan sekaligus tuntutan pada era digital ini. Masa pandemi mengharuskan pengajar dapat berinovasi dalam media dan kurikulum yang tepat (Barber, 2021). Mendukung keberhasilan, berfikir keras tingkat tinggi, inovasi yang perlu di adakan.

Kebermaknaan proses pengajaran dapat menambah informasi dan anak usia dini dapat pengalaman baru dengan IT modern, wali peserta didik sebagai pendamping belajar (Wina, 2014). Dalam proses belajar, media pembelajaran merupakan salah satu penopang proses belajar, peningkatan kemangkusan serta kesangkilan pembelajaran, perlu melakukan pengembangan berbagai model pembelajaran yang kreatif danhal-hal baru (Dina, 2011). Proses belajar dikemas semakin membangkitkan minat, menimbulkan rasa senang serta tidak selalu sama dan berulang didukung dengan penelitian pendidikan bahwa mengidentifikasi, mengukur tingkat keberhasilan di masa pandemi ada kelemahan dan keberhasilan (Bello, 2021). 
Kalangan masyarakat banyak yang mencari solusi dari masalah yang ada. Pantang menyerah dan bekerja sama. Pada proses pembelajaran, media memiliki peran yang sangat penting. Sebab, media dapat menciptakan suasana pembelajaran yang tidak membosankan serta bervariasi. Pendidik menggunakan proses pembelajaran sebagai proses komunikasi menyampaikan informasi kepada peserta didik (Herlambang, 2018). Proses yang dimaksudkan merupakan pendidik memberikan materi pembelajaran yang dibubuhkan ke dalam simbol-simbol komunikasi non verbal maupun verbal. Media yang digunakan oleh pendidik dapat mempengaruhi daya tangkap siswa tersebut saat mengikuti pembelajaran. Hubungan kedekatan pendidik dan peserta didik secara hangat dapat berlangsung baik, dengan dukungan dari wali peserta didik (Wiyani, 2014).

Kecakapan teknologi abad 21 dicanangkan berfikir tinggi, dapat mengemban tugas bersama, inovasi, dan kreativitas. Penelitian menghasilkan pentingnya empat kemahiran oleh peserta didik agar dapat hidup di abad 21 (Selman, 2020). Pendidik abad 21 memiliki pandangan progesif untuk dapat mentranspormasikan diri secara praktik maupun teknik dan kultur sosial. Pendidik diupayakan melek teknologi, mengoperasikan laptop, hp, mengakses web. Pendidik perlu eksistensi diri dalam pengembangan pembelajaran, mengunggah video pembelajaran melintasi whattshap group, facebook, dan instagram. Bahkan ada yang mengadakan lomba-lomba video pembelajaran, disamping bermanfaat untuk pengajaran bisa disampingkan untuk mengikuti perlombaan, mengelola diri lebih baik, mencanangkan paradoks keilmuan (Yamin, 2011). Pendidik sebagai tutorial pengajaran, mengendalikan pembelajaran, penilai peserta didik dan mengadakan evaluasi peserta didik. Transformasi dengan keadaan wali peserta didik menjadi teladan anak mendapatkan penerangan belajar. Dukungan dengan menimba pengetahuan, menambah pemahaman dan mengembangkan keahlian. Teladan wali peserta didik dapat melaksanakan pendampingan anak belajar di rumah dengan proses mengarahkan, memotivasi agar pencapaian prestasi anak maksimal. Anggapan pendidik dan kesiapaan teknik menggunakan media menjadi cara mendukung metode, strategi yang tepat mendukung pembelajaran (Hanif, Asrowi, Sunardi, 2018).

\section{METODE PENELITIAN}

Pada penelitian ini, peneliti menggunakan metode penelitian deskriptif kuantitatif dengan cara mengumpulkan data dalam bentuk skala Likert melalui kuisioner (Arikunto, 2010). Peneliti mendapati sebanyak 100 populasi guru dari 32 lembaga Taman Kanak-kanak, dalam hal ini peneliti menggunakan desain purposive randomsamplingdengan menggunakan sebanyak $25 \%$ sampel pada total 25 guruTaman Kanak-kanak di Kecamatan Kembaran. Kemudian diolah menggunakan perhitungan statistik diperkuat dengan hasil wawancara agar mendalami data yang diperoleh dari kuesioner diharapkan hasil yang diperoleh valid dan obyektif.

\section{HASIL DAN PEMBAHASAN}

Perjalanan penelitian mulai dari proses kegiatan belajar mengajar di kecamatan Kembaran masa pandemi Covid-19 membuat orangtua menjadi pendamping belajar anak, orangtua memiliki kendali penuh dalam proses belajar di rumah. Dalam menyuguhkan materi Guru dengan alat yang tepat (Yamin, 2013). Angket persepsi pendidik menggunakan media pembelajaran menuju abad 21 dimasa pandemi Covid-19 diberi skor 1-4. Skala likert digunakan untuk menakar persepsi, sikap dan pendapat pendidik tentang fenomena sosial, menjadi perhatian dari berbagai pihak Pemerintah dan pemerhati anak usia dini. Penggunaan media pembelajaran yang paling efektif di kecamatan Kembaran dengan penggunaan video sebagai pendukung pengajaran guru, upaya yang dilakukan guru dapat 
mengoperasikan Handphone, laptop, sehingga dapat merancang pembelajaran, dengan kreativitas tinggi sesuai dengan kebutuhan peserta didik dan pendamping peserta didik di rumah.

Situasi yang berbeda mengharuskan dengan pengajaran memintasi online. Pendidik berupaya dengan berbagai cara agar pembelajaran tetap terlaksana walau situasi yang berbeda. Orangtua pun ikut andil menjadi guru di rumah saat anak belajar. Semua pihak bekerjasama, kolaborasi, menghasilkan komunikasi yang positif agar belajar anak sukses. Peneliti ingin mengetahui keberhasilan pengajar di tingkat anak usia dini. Penelitian ini dilakukan berdasarkan hasil evaluasi pengajaran trisemester pertama yang tidak berhasil sesuai dengan harapan orangtua peserta didik. Penelitian pun dilakukan dengan pertimbangan perwakilan dari kecamatan. Diupayakan bisa meluas dengan hasil penelitian yang diadakan di kecamatan Kembaran. Penelitian ini bertujuan untuk membantu pemahaman guru tentang pembelajaran teknologi menggunakan program kerja didukung penelitian dari (Husain, 2021) bahwa seorang guru di Provinsi Gorontalo perlu diupayakan peningkatan kualitas sumber daya manusia menghadapi abad 21 "Teknik operation system pembelajaran TI mampu mengoperasikan dan mengimplementasikan system ke dalam pembelajaran. Studi ini menyelidiki perkembangan disposisi dan sikap termasuk pembangunan kepercayaan diri dan kemampuan anak, dalam empat aspek pembelajaran dan di lima perilaku yang telah ditentukan yang relevan dengan pendidikan teknologi Pengamatan dan wawancara digunakan untuk mengukur pemahaman guru yang dikembangkan tentang pembelajaran anak-anak dalam teknologi penelitian ini didukung (Kurniawan, 2019).

Penelitian bersifat kombinasi data yang dihasilkan berbentuk angka berasal dari pengisian kuesioner, kemudian dideskripsikan secara kualitatif dengan dukungan data dari hasil wawancara. Berdasarkan t-hitung dan t-tabel maka diketahui t-hitung lebih kecil dari t-tabel sehingga t-hitung jatuh diarea $\mathrm{HO}$ dapat disimpulkan bahwa hasil media pembelajaran yang dirancang oleh pendidik mendapat tanggapan yang positif dari peserta didik dan orangtua untuk menuju pembelajaran abad 21. Hasil perhitungan data statistik tujuan membandingkan $t_{\text {tabel }}$ dan $t_{\text {hitung }}$ adalah untuk mengetahui hipotesis $\mathrm{Ho}$ ditolak atau diterima. Pada observasi ini hipotesis yang diterima yaitu $\mathrm{Ha}$, sehingga $\mathrm{Ho}$ ditolak, karena $t_{\text {tabel }(\alpha)}=1,71>t_{\text {hitung }}=-25$, maka Ho ditolak.

Kesiapan dipengaruhi beberapa faktor pendukung media yang tepat sesuai dengan kebutuhan, hasil analisis data kesiapan anak menuju abad 21 dengan pengembangan media dalam program proses pembelajaran anak berfikir kritis, dapat bekerjasama, Komunikasi dan Kreativitas.Kepedulian bagi anak usia dini kaitan dengan wawasan generasi muda pengenalan budaya Indonesia melalui gambar-gambar yang dibuat. Penelitian ini bertujuan untuk desain interaktif media pembelajaran dalam mengenalkan budaya Indonesia khususnya untuk anak usia dini. Hasil penelitianmenunjukkan bahwa: desain media pembelajaran bertema budaya Indonesia dibentuk permainan interaktif, implementasi multimedia interaktif itu menghasilkan proses pembelajaran kelas yang efektif, yang disajikan melalui penilaian ketuntasan hasil belajar sebesar 80\% (Maria, 2019).

Sementara itu faktor yang menghambatyaitu rendahnyapemahaman dan persepsi yang ada, rendahnya pemikiran secara kritis maupun kognitif, minimnya diskusi bersama pendidik lain sertaminimnya kolaborasi bersama mitra yang profesional atau berpengalaman pada duniabelajar mengajar menuju abad 21. Observasi ini dapat ditarik kesimpulan bahwa kesiapan yang dimiliki seorang guru pada media yang digunakan menuju abad 21 (berfikir kritis, kolaborasi, komunikasi dan kreativitas)survei pada guru TK di wilayah Kecamatan Purwokerto Utara mempunyai kesiapansebesar $70 \%$ pada taraf siap atau setuju, Berfikir kritis atau critical Thinkingsebesar $30 \%$ pada taraf isiap atau 
setuju, kesiapan Kolaborasi atau Collaborationsebesar 25\%, kesiapan komunikasi atau Communication $25 \%$ dan Creativity atau Innovation 20\%. Artinya kesiapan guru terhadap penerapan media pembelajaran menuju abad 21 pada guru TK Se-Kecamatan Kembaran sebesar $70 \%$ pada taraf setuju atau siap.Siswa akan menimba ilmu menggunakan metode yang bervariasi pada abad 21 , oleh sebab itu pendidik akan dituntuk untuk berinovasi memberikan pembelajaran kepada peserta didik secara efektif.

Upaya sudah dilakukan dengan baik, melalui berbagai cara zoom, google meet, Whattshap Group Paguyuban, kirim email jika data terlalu banyak, unggah video pembelajaran melalui instagram, facebook, semangat peserta didik, orangtua, guru, dan Pemerintah. Menghantarkan belajar tidak memberatkan, hati senang, dan belajar berhasil mendapat penerangan dari pengajaran. Abad 21 bidang Teknologi Informasi yang sangat canggih (sophisticated), menjadikan duniasempit (Garba et al., 2015; Surya, 2017), kecanggihan teknologi ICT ini mampu diakses dengan instan dan cepat sehingga informasi diperoleh dengan mudah dimanapun tempatnya dan oleh siapapun yang datang mengakses, komunikasi lebih mudah, hemat dimanapun dan kapapun (B Boholano, 2017). Bidang ICT dapat berkembang menyesuaikan abad ke-21 guru diupayakan dapat mengembang tugas secara profesional dalam pendidikan yang terarah di lingkungan kelas abad ke-21 sebagai faktor pendukung yaitu keterlibatan peserta didik, strategi pembelajaran yang efektif,tidak hanya faktor keterampilan guru saja tetapi faktor emosional guru juga mempengaruhi keberhasilan perkembangan anak (Kim et al., 2019; Seidman et al., 2018).

\section{SIMPULAN}

Di era Covid-19 ini sangat tidak mudah melakukan pembelajaran, apa lagi untuk jarak jauh, waktu, kemmapuan guru menghadapi TI, pendampingan orang tua yang sangat menjadi perhatian peneliti, dan kendali belajar anak di rumah. Solusi yang dihadirkan melalui media adalah tonggak utama dalam melakukan pembelajaran. Di era digital media pembelajaran akan mengalami progresif. Penerapan Teknologi Informasi (TI) pada proses belajar mengajar menjadi desakan pertama. Implementasi media belajar mengajar berpokok TI yang berwujud flash disk, mobile phone, internet, dan masih banyak lainnya. Tujuan dari penelitian agar guru dapat menghadapi perkembangan zaman sebagai tuntutan profesi guru, mengembangkan keilmuan dengan teknologi tepat guna untuk pembelajaran anak usia dini, memperdalam video pembelajaran dengan mendalami proses pembuatan video. Pada proses belajar mengajar menggunakan TI sekiranya merupakan sarana yang paling sesuai digunakan pada proses belajar mengajar. Media pembelajaran berbasis TI menunjang siswa dalam memahamisertamenelaah materi pelajaran. Fungsi media padaaktivitas belajar mengajar yaitu menjadi alat peraga serta sarana memberikan informasi saat pembelajaran.

Dalam rangka menghadapi menuju Pendidikan abad 21, pendidik serta peserta didik hendaknya melakukan persiapan menjalani kegiatan belajar mengajar. Transformasi Pendidikan ialah modifikasi watak maupun wajah yang berkenaan pada sistem pendidikan. Dalam rangka menumbuhkan pengetahuan dan kompetensi padapendidik maupun peserta didik dalam menerapkan rumah belajar maka hendaknya dilakukan kegiatan pelatihan, sosialisasi maupunaktivitas sejenis lainnya secara berkelanjutan serta intensif guna untuk menyuluhkan informasi tentang pembelajaran abad 21 serta rumah belajar.

\section{DAFTAR RUJUKAN}

Arikunto, Suharsimi. (2010). Prosedur Penelitian (Suatu Pendekatan Praktik). Jakarta: Rineka Cipta. 
Barber, M., L. Bird, J. Fleming, E. Titterington-Giles, E. Edwards, and C. Leyland. 2021.Gravity Assist: Propelling Higher Education Towards a Brighter Future. Report of the digital learning and teaching review. London: Office for Students.

B Boholano, H. (2017). Smart Social Networking: 21st Century Teaching and Learning Skills Research in Pedagogy, 7(1), 21-29. $\quad$ https://doi.org/10.17810/2015.45

Bello, A. 2021. "How Test Publishers are Poised to Profit from Pandemic 'Learning Loss'." Forbes, April 7. https://www.forbes.com/sites/akilbello/2021/04/07/how-test-publishers-are-poised-to-profitfrom-pandemic-learning-loss/

Decuypere, M., E. Grimaldi, and P. Landri. 2021. "Introduction: Critical Studies of Digital Education Platforms." Critical Studies in Education.

Garba, S. A., Byabazaire, Y., \& Busthami, A. H. (2015). Toward the use of 21 st century teachinglearning approaches: The trend of development in Malaysian schools within the context of Asia Pacific. International Journal of Emerging Technologies in Learning, 10(4), 72-79. https://doi.org/10.3991/ijet.v10i4.4717

Hanif, M., \& Asrowi. (2018). Mobile learning perception of graduate student teachers: A case study in magister program of educational technology of university of Sebelas Maret. International Journal of Multicultural and Multireligious Understanding Journal of Education and Learning, $5(1)$

Herlambang, Y. T. (2018). Pedagogik Telaah Kritis IImu Pendidikan Dalam Multiperspektif. Jakarta: Bumi Aksara.

Husain, Rusmin, ANto Kaharu. ( 2021). Menghadapi Era Abad 21: Tantangan Guru Pendidikan Anak Usia Dini di Kabupaten Bone Bolango.Volume 5 Issue 1 Pages 85-92. ISSN: 2549-8959 (Online) 2356-1327 (Print).

\section{DOI: $\quad 10.31004 / 0 b s e s i . v 5 i 1.527$}

Hutami, M. S., \& Nugraheni, A. S. (2020). Metode Pembelajaran Melalui Whatsapp Group Sebagai Antisipasi Penyebaran Covid-19 pada AUD di TK ABA Kleco Kotagede. PAUDIA : Jurnal Penelitian Dalam Bidang Pendidikan Anak Usia Dini, 9(1), 126-130

Indriana, Dina. (2011). Ragam Alat Bantu Media Pengajaran. Jakarta: PT Diva Press

Kim, S., Raza, M., \& Seidman, E. (2019). Improving 21st-century teaching skills: The key to effective 21st-century learners. Research in Comparative and International Education, 14(1), 99-117. $\quad$ https://doi.org/10.1177/1745499919829214

Kurniawan, Adi Purna, Niswa Nafiah Sartono. (2019). Multimedia Augmented Reality Technology in Daily Basic Knowledge Learning Media for Early Childhood and Kindergarten. Int. Journal of Applied ITVol. 03No.01International Journal of Applied Information Technology. http://journals.telkomuniversity.ac.id/ijait/

Marcomm, M. (2018). Millennials. Jakarta: Fantasious X

Maria, Ulfa Ani Rusilowati, and Wahyu Hasrdynto. Interactive Multimedia Development in The Learning Process of Indonesian Culture Introduction Theme for 5-6 Year Old Children. Journal of Primary Education 8(3)(2019):344-353

https://journal.unnes.ac.id/sju/index.php/jpe/article/view/27929

Sanjaya, Wina. (2014). Media Komunikasi Pembelajaran. Jakarta: Kencana Perdana

Media Group 
Efektor, Volume 8 Issue 1, 2021, Pages 45-52

Desti Pujiati, Dema Yulianto

Selman, Yohanes Fakundo. (2020). Evaluation of The Implementation of 4C Skills in Indonesian Subject at Senior High Schools. Jurnal : JPI, Vol. 9 No. 2, June 2020 DOI: 10.23887/jpi-undiksha.v9i2.23459

Wiyani, Novan Ardy. (2014). Psikologi Perkembangan Anak Usia Dini. Yogyakarta: Gava Media Yamin, Martinis. 2011. Pardigma Baru Pembelajaran. Jakarta: Penerbit Gaung Persada Press

Yamin, Martinis. 2013. Strategi dan Metode dalam Model Pembelajaran. Jakarta: GP Press Group 